\title{
What is the ideal route of administration of tranexamic acid in total knee arthroplasty? A meta-analysis based on randomized controlled trials
}

\author{
Feifan Lu" ${ }^{1 \#}$, Xiaowei Sun ${ }^{2 \#}$, Weiguo Wang ${ }^{3}$, Qidong Zhang ${ }^{3}$, Wanshou Guo ${ }^{3}$ \\ ${ }^{1}$ Peking University China-Japan Friendship School of Clinical Medicine, Beijing, China; ${ }^{2}$ Graduate School of Peking Union Medical College and \\ Chinese Academy of Medical Sciences, Beijing, China; ${ }^{3}$ Department of Orthopedic Surgery, Beijing Key Lab Immune-Mediated Inflammatory \\ Diseases, China-Japan Friendship Hospital, Peking Union Medical School, Beijing, China \\ Contributions: (I) Conception and design: All authors; (II) Administrative support: W Guo, W Wang; (III) Provision of study materials or patients: \\ F Lu, X Sun, W Wang; (IV) Collection and assembly of data: F Lu, Q Zhang; (V) Data analysis and interpretation: All authors; (VI) Manuscript \\ writing: All authors; (VII) Final approval of manuscript: All authors. \\ \#These authors contribute equally to this work and are co-first authors. \\ Correspondence to: Qidong Zhang, MD; Wanshou Guo, MD. Department of Orthopedic Surgery, Beijing Key Lab Immune-Mediated Inflammatory \\ Diseases, China-Japan Friendship Hospital, Peking Union Medical School, Beijing, China. Email: zhangqidong1982@sina.com; guowanshou@pku.edu.cn.
}

Backgroundk Tranexamic acid (TXA) was conducive in total knee arthroplasty (TKA) to reduce blood loss and transfusion demand. The purpose of this meta-analysis was to assess the efficacy and safety of different administration of TXA in primary TKA.

Methods: Database PubMed, Medline, Web of Science and Embase were searched. The relative risks (RRs) with 95\% confidence intervals (CIs) were calculated to analysis dichotomous outcomes. The mean differences (MD) with 95\% CIs were calculated to analysis dichotomous outcomes. Data was analyzed using RevMan 5.3.

Results: Twenty-eight randomized controlled trials (RCTs) studies were included in this meta-analysis involving a total of 4,200 participants. There were no obvious differences between oral, intravenous or topical TXA group in total blood loss (intravenous vs. topical: $\mathrm{MD}=11.55,95 \% \mathrm{CI},-10.23$ to 33.34 , oral vs. intravenous or topical: $\mathrm{MD}=-52.25,95 \% \mathrm{CI},-121.28$ to 16.78 ), transfusion rate (intravenous vs. topical: $\mathrm{RR}=1.04,95 \% \mathrm{CI}, 0.64$ to 1.69 , oral $v$ s. intravenous or topical: $\mathrm{RR}=0.75,95 \% \mathrm{CI}, 0.36$ to 1.54$)$, incidence of venous thrombotic events (VTE) (intravenous $v$ s. topical: $\mathrm{RR}=1.43,95 \% \mathrm{CI}, 0.81$ to 2.54 ). The topical TXA administration had significantly increased postoperative hemoglobin (HB) level compared with the intravenous TXA administration ( $\mathrm{MD}=-0.37,95 \% \mathrm{CIs},-0.47$ to -0.26 ). In the combined group, the total blood loss (MD =-119.58, 95\% CI, -181.68 to -57.49$)$ and postoperative HB level (MD =0.54, 95\% CI, 0.45 to 0.64 ) were more acceptable than the single-route group.

Conclusions: Combined administration of TXA can reduce total blood loss, postoperative HB drop compared with intravenous, topical or oral TXA alone. Oral administration of TXA is similar to intravenous or topical TXA use alone.

Keywords: Total knee arthroplasty (TKA); tranexamic acid (TXA); meta-analysis

Submitted Sep 15, 2020. Accepted for publication Nov 06, 2020.

doi: 10.21037/apm-20-1857

View this article at: http://dx.doi.org/10.21037/apm-20-1857 


\section{Introduction}

Total knee arthroplasty (TKA) was a common method for the treatment of elderly patients with end-stage knee osteoarthritis. However, average blood loss after TKA has been noted to range from $500-1,500 \mathrm{~mL}$, resulting in about $40-50 \%$ of the patients undergoing TKA unavoidably experience postoperative anemia $(1,2)$.

In the past two decades, the role of Tranexamic acid (TXA) in TKA has been a concern and the application of TXA also been studied a lot to limit the rate of blood loss and transfusion (3-5). Previous studies have indicated that TXA was related to the significant reduction of blood loss and transfusion demand $(6,7)$. In addition, previous studies also indicated that oral and intravenous TXA had similar hemostatic effect $(8,9)$. And relevant studies have shown that patients receiving combined topical and intravenous TXA benefit more than patients receiving a single route of TXA $(10,11)$. In particular, surgeons have been worried about the occurrence of venous thromboembolism (VTE) in high-risk patients using TXA. Recently, some new randomized controlled trials (RCTs) have been carried out to study this problem. Therefore, we conducted this meta-analysis to discuss the efficacy and safety of different TXA administration methods with regard to blood loss, postoperative hemoglobin (HB) level, the incidence of VTE and blood transfusion.

This meta-analysis was conducted according to the Preferred Reporting Items for Systematic Reviews and Meta-Analyses (PRISMA) guidelines (available at http:// dx.doi.org/10.21037/apm-20-1857) (12).

\section{Methods}

\section{Literature search strategy}

The study was conducted in accordance with the Declaration of Helsinki (as revised in 2013). This metaanalysis does not require the approval of the ethics committee. Literature search was conducted by using the electronic databases PubMed, Medline, Web of Science and Embase (last search was updated on March 31, 2020). The following keywords were used to search the data base: ("TKA" OR "Total knee arthroplasty") AND ("tranexamic acid" OR "TXA") AND ("randomized controlled trials" OR "RCT"). The included literatures must be written in English.

\section{Inclusion and exclusion criteria}

Inclusion criteria: (I) RCTs; (II) patients: underwent TKA (III) groups including topical TXA, intravenous TXA, oral TXA or combination; (IV) complete outcome data. Reviews, case reports, biochemical studies, letters, and conference abstracts were excluded.

\section{Data extraction}

All data were extracted by two independent researchers according to the criteria. A data extraction table was provided including the year of publication, first author's name, simple sizes, mean ages, male (\%), comparison types, Intravenous regimen, topical regimen, oral regimen, surgery, tourniquet use, calculation method of blood loss, time of postoperative evaluation of $\mathrm{Hb}$, evaluation method of VTE and the indications of blood transfusion.

\section{Study quality assessment}

Study quality assessment was conducted by using the Cochrane Collaboration's tool to assess the risk of bias. This tool was conducted by the following 6 items: sequence generation, allocation concealment, blinding of participants, personnel and outcome assessors, incomplete outcome data, selective outcome reporting, and other sources of bias. The results were classified into three grades: "low risk, middle risk, and high risk".

\section{Statistical analysis}

The relative risks (RRs) with $95 \%$ confidence intervals (CIs) were calculated to analysis dichotomous outcomes. The mean differences (MD) with 95\% CIs were calculated to analysis dichotomous outcomes. The $\mathrm{P}$ value of $\mathrm{Q}$ statistic test and $\mathrm{I}^{2}$ statistic were used to assess statistical heterogeneity (13). A random effects model was applied If $\mathrm{I}^{2}<50 \%$ and $\mathrm{P}$ value lower than 0.10 . Subgroup analysis was carried out according to the following variables: surgery (bilateral TKA or unilateral TKA), topical dose ( $\geq 3$ or $<3 \mathrm{~g}$ ), intravenous dose ( $\geq 3$ or $<3 \mathrm{~g}$ ), tourniquet (use or not use), region (Asia, Europe or North America). Publication bias was assessed by using funnel plot. Sensitivity analysis determines the impact on heterogeneity testing by eliminating each study in turn, and evaluates the stability of the overall results. All statistical analyses were conducted 


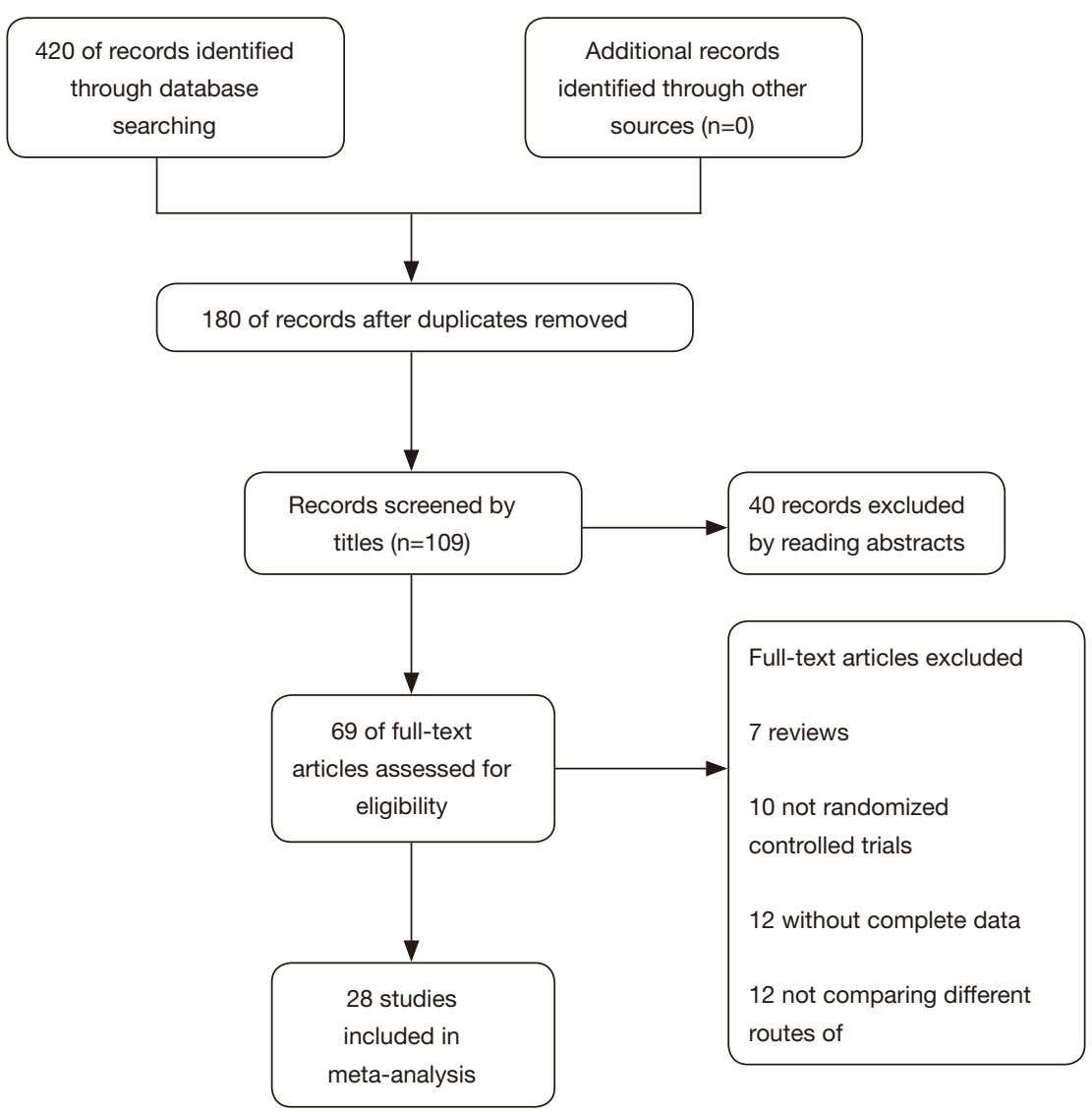

Figure 1 Flowchart of the literature search and selection for the present study.

in Review Manager Software (RevMan version 5.3, the Cochrane Collaboration, Copenhagen, Denmark).

\section{Results}

\section{Characteristics of the included studies}

A total of 420 records were retrieved from the database, and 180 remained after eliminating duplicate documents. Then, 109 records were screened by titles, and 40 records were excluded after reviewing the abstracts. We reviewed the full text of the remaining 69 records and excluded 41 citations for reasons such as reviews, not RCTs and without sufficient data (Figure 1). Finally, we identified 28 RCTs studies in this meta-analysis and involved a total of 4,200 participants. Study quality assessment and other features of the included studies were shown in Tables 1,2.

\section{Topical versus intravenous route}

\section{Blood loss}

Twelve studies involving 1,260 patients that reported blood loss were included. No significant difference was observed in the total blood loss (MD, 11.55 ; $95 \% \mathrm{CI},-10.23$ to 33.34; $\mathrm{P}=0.30 ; \mathrm{I}^{2}=28.0 \%$; fixed effect model) between intravenous TXA administration and topical administration (Figure 2A).

\section{Postoperative HB level}

Twelve studies involving 1,309 patients that reported postoperative HB level were included. The data showed that the topical TXA administration had significant increased postoperative HB level compared with the intravenous TXA administration (MD, -0.37 ; $95 \% \mathrm{CI},-0.47$ to -0.26 ; $\mathrm{P}<0.001 ; \mathrm{I}^{2}=34.0 \%$; fixed effect model) (Figure $2 B$ ). 


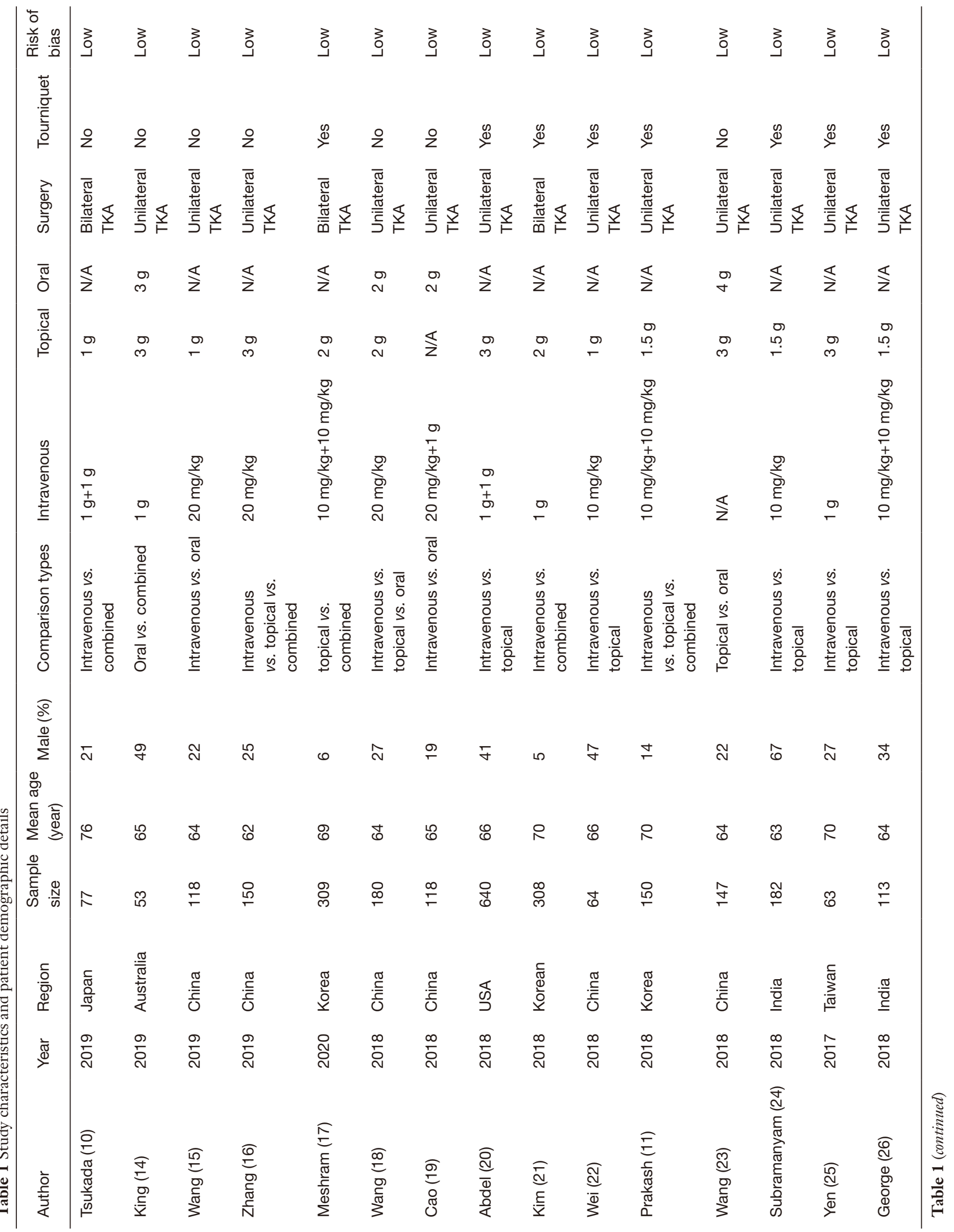




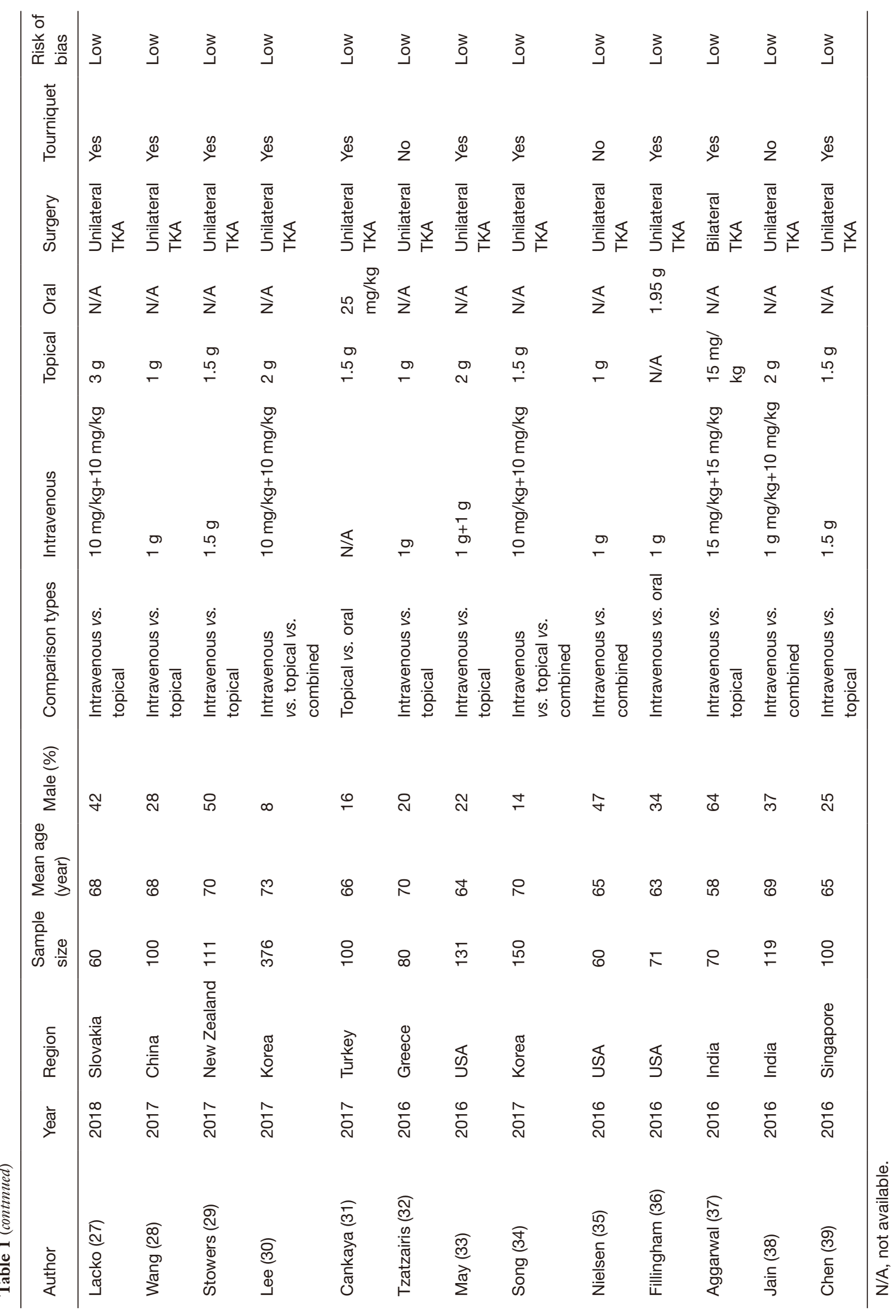


Table 2 Study characteristic

\begin{tabular}{|c|c|c|c|c|c|}
\hline Author & Year & $\begin{array}{l}\text { Calculation method of } \\
\text { blood loss }\end{array}$ & $\begin{array}{l}\text { Time of postoperative } \\
\text { evaluation of } \mathrm{Hb}\end{array}$ & $\begin{array}{l}\text { Evaluation } \\
\text { method of VTE }\end{array}$ & Indications of blood transfusion \\
\hline Tsukada (10) & 2019 & Formula from Nadler & Postoperative day 3 & Clinical & $\begin{array}{l}\mathrm{Hb}<70 \mathrm{~g} / \mathrm{L} \text { in asymptomatic patients } \\
\text { or between } 70 \mathrm{~g} / \mathrm{L} \text { and } 100 \mathrm{~g} / \mathrm{L} \text { in } \\
\text { symptomatic patients }\end{array}$ \\
\hline King (14) & 2019 & $\begin{array}{l}\text { The volume of theatre } \\
\text { and drain blood loss }\end{array}$ & Postoperative day 2 & Clinical & $\mathrm{Hb}<80 \mathrm{~g} / \mathrm{L}$ \\
\hline Zhang (16) & 2019 & $\begin{array}{l}\text { The fluid in the aspirator } \\
\text { plus the weight gain of } \\
\text { the hemostatic cloth }\end{array}$ & Postoperative day 3 & Clinical & $\mathrm{N} / \mathrm{A}$ \\
\hline Wang (18) & 2018 & Formula from Nadler & Postoperative day 3 & Clinical & $\begin{array}{l}\mathrm{Hb}<70 \mathrm{~g} / \mathrm{L} \text { in asymptomatic patients or } \\
\text { organ dysfunction patients }\end{array}$ \\
\hline Cao (19) & 2018 & Formula from Nadler & Postoperative day 3 & $\mathrm{~N} / \mathrm{A}$ & $\begin{array}{l}\mathrm{Hb}<70 \mathrm{~g} / \mathrm{L} \text { in asymptomatic patients } \\
\text { or between } 70 \mathrm{~g} / \mathrm{L} \text { and } 100 \mathrm{~g} / \mathrm{L} \text { in } \\
\text { symptomatic patients }\end{array}$ \\
\hline Abdel (20) & 2018 & Formula from Nadler & Postoperative day 1 & Clinical & $\begin{array}{l}\mathrm{Hb}<80 \mathrm{~g} / \mathrm{L} \text { in asymptomatic patients or } \\
<100 \mathrm{~g} / \mathrm{L} \text { anemic symptoms }\end{array}$ \\
\hline $\operatorname{Kim}(21)$ & 2018 & $\begin{array}{l}\text { The volume of blood } \\
\text { in suction drains and } \\
\text { weighing the swabs used }\end{array}$ & Postoperative day 2 & Clinical & $\begin{array}{l}\mathrm{Hb}<70 \mathrm{~g} / \mathrm{L} \text { in asymptomatic patients or } \\
>70 \mathrm{~g} / \mathrm{L} \text { with anemic symptoms }\end{array}$ \\
\hline Subramanyam (24) & 2018 & $\begin{array}{l}\text { Formula from Nadler and } \\
\text { Sehat }\end{array}$ & Postoperative day 3 & Ultrasound & $\begin{array}{l}\mathrm{Hb}<80 \mathrm{~g} / \mathrm{L} \text { in asymptomatic patients } \\
\text { or between } 80 \mathrm{~g} / \mathrm{L} \text { and } 100 \mathrm{~g} / \mathrm{L} \text { in } \\
\text { symptomatic patients }\end{array}$ \\
\hline Yen (25) & 2017 & Formula from Nadler & Postoperative day 2,4 & Clinical & $\begin{array}{l}\mathrm{Hb}<80 \mathrm{~g} / \mathrm{L} \text { in asymptomatic patients } \\
\text { or between } 80 \mathrm{~g} / \mathrm{L} \text { and } 90 \mathrm{~g} / \mathrm{L} \text { in } \\
\text { symptomatic patients }\end{array}$ \\
\hline George (26) & 2018 & $\begin{array}{l}\text { Calculated } \\
\text { intraoperatively }\end{array}$ & Postoperative day 3 & Ultrasound & $\mathrm{Hb}<70 \mathrm{~g} / \mathrm{L}$ \\
\hline Lacko (27) & 2018 & In drainage & Postoperative day 2 & Ultrasound & $\begin{array}{l}\mathrm{Hb}<80 \mathrm{~g} / \mathrm{L} \text { in asymptomatic patients or } \\
<90 \mathrm{~g} / \mathrm{L} \text { in symptomatic patients }\end{array}$ \\
\hline Wang (28) & 2017 & $\begin{array}{l}\text { Formula from Nadler and } \\
\text { Sehat }\end{array}$ & Postoperative day 2 & Ultrasound & $\begin{array}{l}\mathrm{Hb}<60 \mathrm{~g} / \mathrm{L} \text { in asymptomatic patients or } \\
>60 \mathrm{~g} / \mathrm{L} \text { in symptomatic patients }\end{array}$ \\
\hline Stowers (29) & 2017 & $\begin{array}{l}\text { Formula described by } \\
\text { Good }\end{array}$ & $\begin{array}{l}\text { Postoperative } \\
\text { day } 1,2,3\end{array}$ & Clinical & $\begin{array}{l}\mathrm{Hb}<80 \mathrm{~g} / \mathrm{L} \text { in asymptomatic patients or } \\
<100 \mathrm{~g} / \mathrm{L} \text { in symptomatic patients }\end{array}$ \\
\hline
\end{tabular}

Table 2 (continued) 
Table 2 (continued)

\begin{tabular}{|c|c|c|c|c|c|}
\hline Author & Year & $\begin{array}{l}\text { Calculation method of } \\
\text { blood loss }\end{array}$ & $\begin{array}{l}\text { Time of postoperative } \\
\text { evaluation of } \mathrm{Hb}\end{array}$ & $\begin{array}{l}\text { Evaluation } \\
\text { method of VTE }\end{array}$ & Indications of blood transfusion \\
\hline Lee (30) & 2017 & $\begin{array}{l}\text { Formula described by } \\
\text { Good and Nadler }\end{array}$ & Postoperative day 5 & Clinical & $\begin{array}{l}\mathrm{Hb}<70 \mathrm{~g} / \mathrm{L} \text { in asymptomatic patients } \\
\text { or between } 70 \mathrm{~g} / \mathrm{L} \text { and } 80 \mathrm{~g} / \mathrm{L} \text { in } \\
\text { symptomatic patients }\end{array}$ \\
\hline Cankaya (31) & 2017 & Formula from Gross & Postoperative day 2 & Clinical & $\begin{array}{l}\mathrm{Hb}<85 \mathrm{~g} / \mathrm{L} \text { in asymptomatic patients or } \\
\text { symptomatic patients }\end{array}$ \\
\hline May (33) & 2016 & Formula from Nadler & $\begin{array}{l}\text { Postoperative } \\
\text { day } 1,2,3\end{array}$ & Clinical & $\begin{array}{l}\mathrm{Hb}<70 \mathrm{~g} / \mathrm{L} \text { in asymptomatic patients or } \\
<100 \mathrm{~g} / \mathrm{L} \text { anemic symptoms }\end{array}$ \\
\hline Song (34) & 2017 & $\begin{array}{l}\text { Formula from Gross and } \\
\text { Nadler }\end{array}$ & $\begin{array}{l}\text { Postoperative } \\
\text { day } 1,2,4\end{array}$ & Ultrasound & $\mathrm{Hb}<80 \mathrm{~g} / \mathrm{L}$ \\
\hline Fillingham (36) & 2016 & $\begin{array}{l}\text { Formula from Gross and } \\
\text { Nadler }\end{array}$ & $\mathrm{N} / \mathrm{A}$ & N/A & $\begin{array}{l}\mathrm{Hb}<70 \mathrm{~g} / \mathrm{L} \text { in asymptomatic patients or } \\
>70 \mathrm{~g} / \mathrm{L} \text { in symptomatic patients }\end{array}$ \\
\hline Aggarwal (37) & 2016 & $\begin{array}{l}\text { Formula from Good and } \\
\text { Nadler }\end{array}$ & Postoperative day 3 & $\mathrm{~N} / \mathrm{A}$ & $\mathrm{Hb}<80 \mathrm{~g} / \mathrm{L}$ \\
\hline Jain (38) & 2016 & Formula from Nadler & $\mathrm{N} / \mathrm{A}$ & Ultrasound & $\begin{array}{l}\mathrm{Hb}<70 \mathrm{~g} / \mathrm{L} \text { in asymptomatic patients } \\
\text { or between } 70 \mathrm{~g} / \mathrm{L} \text { and } 80 \mathrm{~g} / \mathrm{L} \text { in } \\
\text { symptomatic patients }\end{array}$ \\
\hline Chen (39) & 2016 & Formula from Nadler & Postoperative day 4 & Ultrasound & $\mathrm{Hb}<80 \mathrm{~g} / \mathrm{L}$ \\
\hline
\end{tabular}

$\mathrm{N} / \mathrm{A}$, not available; $\mathrm{Hb}$, hemoglobin; VTE, venous thrombotic events.

\section{VTE rate}

Nine studies involving 1,547 patients that reported VTE rate were included. No significant difference was observed in the VTE rate (RR, 1.43; 95\% CI, 0.81 to 2.54; $\mathrm{P}=0.22 ; \mathrm{I}^{2}=0 \%$; fixed effect model) between topical TXA administration and intravenous administration (Figure 2C).

\section{Transfusion rate}

Fourteen studies involving 1,536 patients that reported transfusion rate were included in the analysis. No significant difference was observed in the transfusion rate $(\mathrm{RR}, 1.04$; $95 \%$ CI, 0.64 to $1.69 ; \mathrm{P}=0.88 ; \mathrm{I}^{2}=7 \%$; fixed effect model) between intravenous TXA administration and topical administration (Figure 2D).

\section{Oral vs. intravenous or topical}

\section{Blood loss}

Four studies that reported blood loss were included in this analysis. Two studies involving 191 patients compared oral TXA with intravenous TXA and two studies involving 267 patients compared oral TXA with topical TXA. No significant difference was observed in the total blood loss between oral TXA administration and intravenous or topical administration (vs. intravenous: $\mathrm{MD},-27.61 ; 95 \%$ CI, -129.69 to $74.47 ; \mathrm{P}=0.60$; vs. topical: $\mathrm{MD},-73.01 ; 95 \%$ CI, -166.71 to $20.69 ; \mathrm{P}=0.13$ ) (Figure 3 A).

\section{Postoperative HB level}

Five studies that reported postoperative HB level were included in this analysis. Three studies involving 471 patients compared oral TXA with intravenous TXA and two studies involving 267 patients compared oral TXA with topical TXA. No significant difference was observed in the postoperative HB level between oral TXA administration and intravenous or topical administration ( $v s$. intravenous: $\mathrm{MD},-0.02 ; 95 \% \mathrm{CI},-0.07$ to $0.12, \mathrm{P}=0.61$; vs. topical: $\mathrm{MD}$, $0.21 ; 95 \% \mathrm{CI},-0.09$ to $0.52 ; \mathrm{P}=0.67$ ) (Figure $3 B$ ). 
A

\begin{tabular}{|c|c|c|c|c|c|c|c|c|c|c|c|}
\hline \multirow[b]{2}{*}{ Stuctv or Subgroup } & \multicolumn{3}{|c|}{ Intravenous } & \multicolumn{2}{|c|}{ tropic } & \multirow[b]{2}{*}{ Total } & \multicolumn{2}{|r|}{ Mean Difference } & \multirow{2}{*}{\multicolumn{3}{|c|}{$\begin{array}{l}\text { Mean Difference } \\
\text { V. Fixed, } 95 \% \mathrm{CI}\end{array}$}} \\
\hline & Mean & SD & Total & Mean & SD & & Weight & IV. Fixed, $95 \% \mathrm{Cl}$ & & & \\
\hline Chen2016 & 730 & 195 & 50 & 799 & 268 & 50 & $5.6 \%$ & $-69.00[-160.87,22.87]$ & & F & \\
\hline George2018 & 661 & 124 & 55 & 672 & 136 & 58 & $20.6 \%$ & $-11.00[-58.95,36.95]$ & & & \\
\hline Lacko2018 & 580 & 220 & 30 & 600 & 200 & 30 & $4.2 \%$ & $-20.00[-126.39,86.39]$ & & & \\
\hline May2017 & 806 & 368 & 69 & 835 & 318 & 62 & $3.4 \%$ & $-29.00[-146.49,88.49]$ & & & \\
\hline Prakash2018 & 1,208 & 368 & 50 & 1,198 & 356 & 50 & $2.4 \%$ & $10.00[-131.92,151.92]$ & & & \\
\hline Song2017 & 972 & 268 & 50 & 998 & 256 & 50 & $4.5 \%$ & $-26.00[-128.73,76.73]$ & & & \\
\hline Stower2017 & 749 & 111 & 51 & 723 & 103 & 60 & $29.5 \%$ & $26.00[-14.09,66.09]$ & & - & \\
\hline Subramanyam 2018 & 571 & 119 & 91 & 565 & 222 & 91 & $17.7 \%$ & $6.00[-45.75,57.75]$ & - & & \\
\hline Tzatzairis2017 & 1,236 & 307 & 40 & 1,205 & 300 & 40 & $2.7 \%$ & $31.00[-102.02,164.02]$ & & & \\
\hline Wang2017 & 919 & 328 & 50 & 770 & 237 & 50 & $3.8 \%$ & $149.00[36.83,261.17]$ & & & \\
\hline Wang2018 & 1,108 & 392 & 60 & 1,059 & 422 & 60 & $2.2 \%$ & $49.00[-96.74,194.74]$ & & & \\
\hline Yen2018 & 921 & 252 & 31 & 795 & 231 & 32 & $3.3 \%$ & $126.00[6.52,245.48]$ & & & \\
\hline Total $(95 \% \mathrm{Cl})$ & & & 627 & & & 633 & $100.0 \%$ & $11.55[-10.23,33.34]$ & & & \\
\hline $\begin{array}{l}\text { Heterogeneity: } \mathrm{Chi}^{2}= \\
\text { Test for overall effect: }\end{array}$ & $\begin{array}{l}15.28, d f \\
Z=1.04\end{array}$ & $\begin{array}{l}=11 \\
(P=0.3\end{array}$ & & & & & & & $\begin{array}{cc}-200 & -100 \\
\text { Favours [topical] } & \\
\end{array}$ & 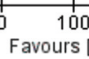 & $\begin{array}{l}200 \\
\text { travenou }\end{array}$ \\
\hline
\end{tabular}

B

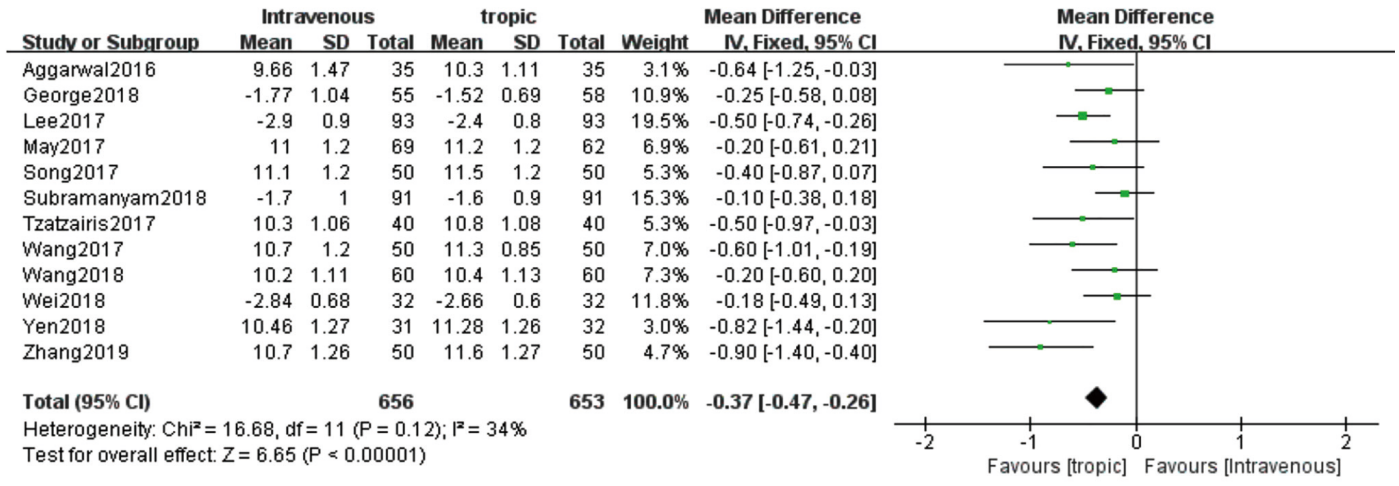

C

\begin{tabular}{|c|c|c|c|c|c|c|c|c|c|c|}
\hline \multirow[b]{2}{*}{ Studv or Subgroup } & \multicolumn{2}{|c|}{ Intravenous } & \multicolumn{2}{|c|}{ tropic } & \multirow{2}{*}{\multicolumn{2}{|c|}{ Risk Ratio }} & \multirow{2}{*}{\multicolumn{3}{|c|}{$\begin{array}{c}\text { Risk Ratio } \\
\text { M-H. Fixed, 95\% Cl }\end{array}$}} & \\
\hline & Events & Total & Events & Iotal & & M-H, Fixed, $95 \% \mathrm{Cl}$ & & & & \\
\hline Abdel2018 & 5 & 320 & 2 & 320 & $10.8 \%$ & $2.50[0.49,12.79]$ & & & & \\
\hline May2017 & 4 & 69 & 2 & 62 & $11.4 \%$ & $1.80[0.34,9.47]$ & & & & \\
\hline Prakash2018 & 3 & 50 & 1 & 50 & $5.4 \%$ & $3.00[0.32,27.87]$ & & & & \\
\hline Stower2017 & 1 & 51 & 2 & 60 & $10.0 \%$ & $0.59[0.05,6.30]$ & & & & \\
\hline Subramanyam 2018 & 0 & 91 & 1 & 91 & $8.1 \%$ & $0.33[0.01,8.08]$ & & & & \\
\hline Wang2017 & 1 & 50 & 1 & 50 & $5.4 \%$ & $1.00[0.06,15.55]$ & & & & \\
\hline Wang2018 & 1 & 60 & 0 & 60 & $2.7 \%$ & $3.00[0.12,72.20]$ & & & & \\
\hline Yen2018 & 1 & 31 & 0 & 32 & $2.7 \%$ & $3.09[0.13,73.17]$ & & & & \\
\hline Zhang2019 & 9 & 50 & 8 & 50 & $43.4 \%$ & $1.13[0.47,2.68]$ & & & & \\
\hline Total $(95 \% \mathrm{Cl})$ & & 772 & & 775 & $100.0 \%$ & $1.43[0.81,2.54]$ & & & & \\
\hline Total events & 25 & & 17 & & & & & & & \\
\hline $\begin{array}{l}\text { Heterogeneity: } \mathrm{Chi}^{2}= \\
\text { Test for overall effect: }\end{array}$ & $\begin{array}{l}.08, \mathrm{df}= \\
=1.23(\mathrm{~F}\end{array}$ & $\begin{array}{l}(P=0 . \\
=0.22)\end{array}$ & 93); $\left.\right|^{2}=0$ & & & & 0.001 & $\begin{array}{c}0.1 \\
\text { Favours [tropic] }\end{array}$ & $\begin{array}{r}10 \\
\text { Favours [ }\end{array}$ & 100 \\
\hline
\end{tabular}

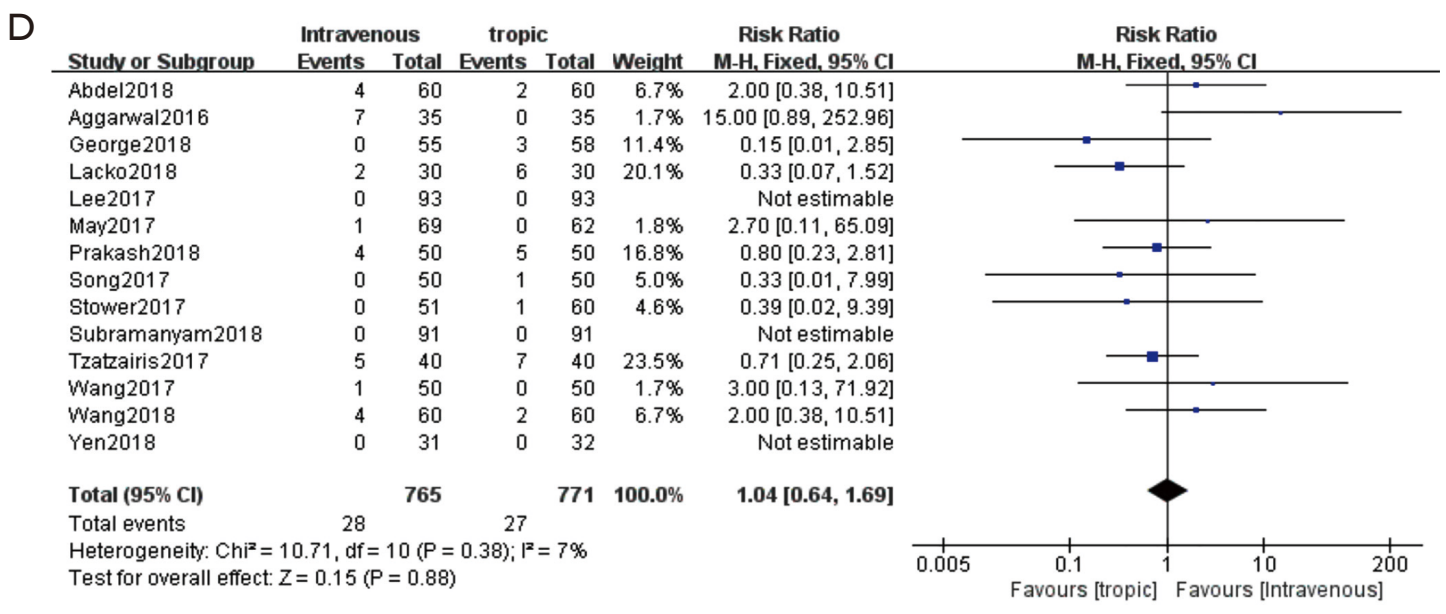

Figure 2 Forest plot between intravenous and topical tranexamic acid (A) blood loss. (B) Hemoglobin level. (C) venous thrombotic events rate. (D) transfusion rate. 
A

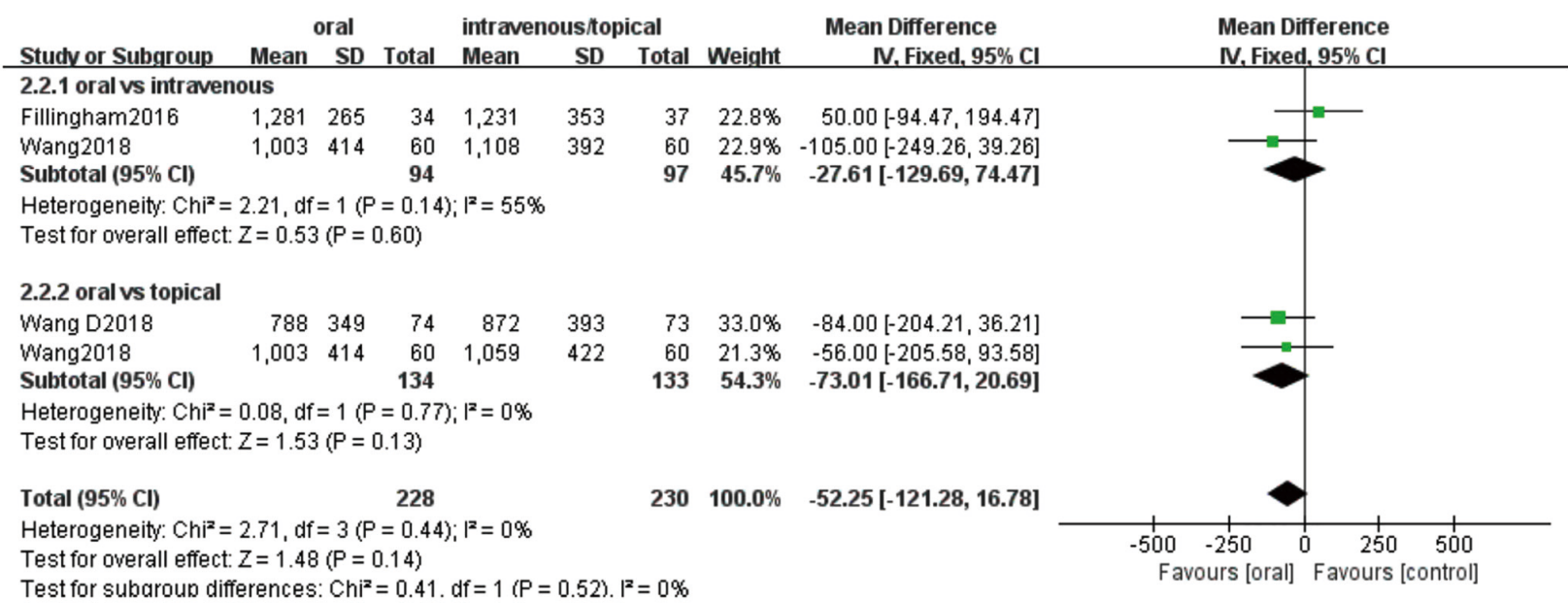

B

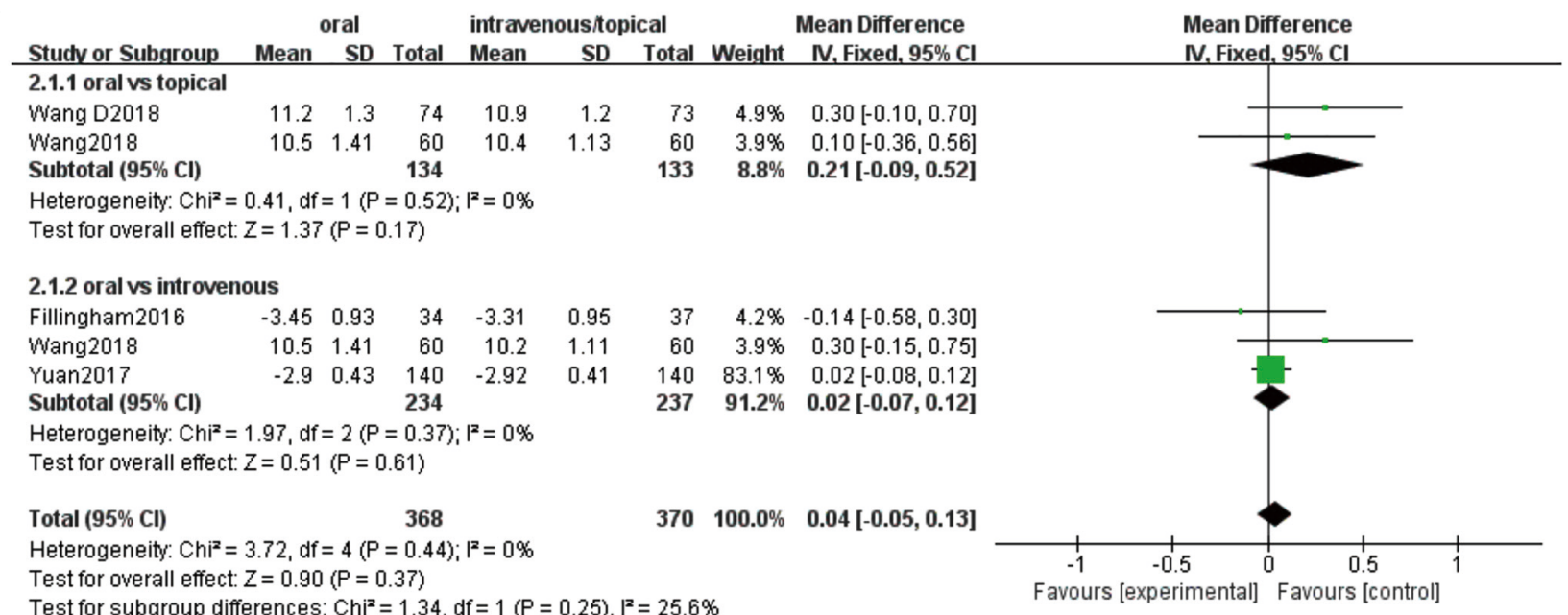

C

Test for subaroun differences: $\mathrm{Chi}^{2}=1.34 . \mathrm{df}=1(\mathrm{P}=0.25) . \mathrm{I}^{2}=25.6 \%$

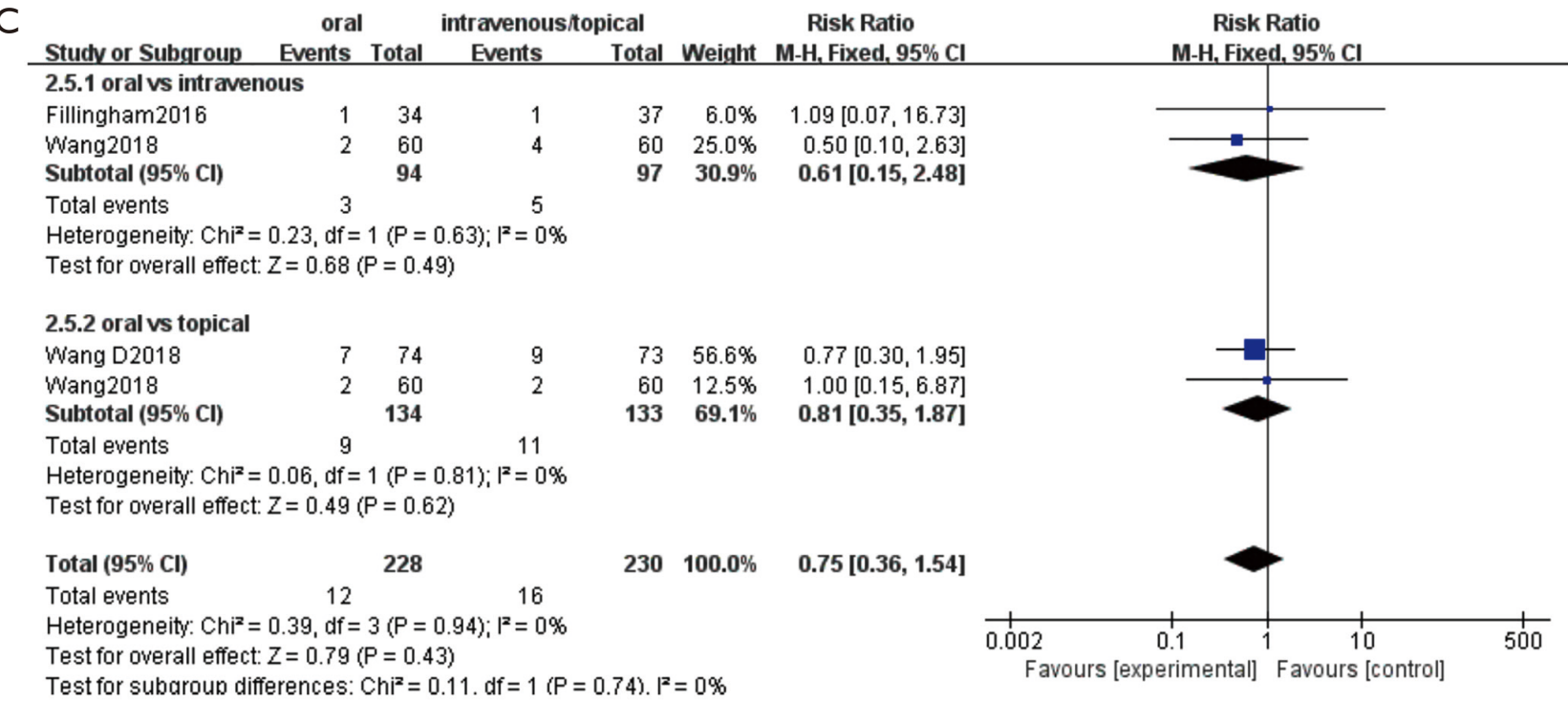

Figure 3 Forest plot between oral and intravenous or topical tranexamic acid (A) blood loss. (B) Hemoglobin level. (C) transfusion rate. 


\section{Transfusion rate}

Four studies reported transfusion rate were included in this analysis. Two studies involving 191 patients compared oral TXA with intravenous TXA and two studies involving 267 patients compared oral TXA with topical TXA. No significant difference was observed in the transfusion rate between oral TXA administration and intravenous or topical administration (vs. intravenous: RR, 0.61; 95\% CI, 0.15 to $2.48 ; \mathrm{P}=0.49 ;$ vs. topical: $\mathrm{RR}, 0.81 ; 95 \% \mathrm{CI}, 0.35$ to 1.87; $\mathrm{P}=0.62$ ) (Figure 3C).

\section{Combined vs. single route}

\section{Blood loss}

Fourteen studies were included in this analysis. Nine studies involving 1,188 patients compared combined TXA route with intravenous TXA and five studies involving 774 patients compared combined TXA route with topical TXA. The results showed that the combined route had significantly decreased total blood loss (MD, -199.58; 95\% CI, -181.68 to $-57.49 ; \mathrm{P}<0.001 ; \mathrm{I}^{2}=86 \%$ ) compared with the single regimen. Compared with the intravenous (MD, $-134.00 ; 95 \% \mathrm{CI}, 228.10$ to $-39.89 ; \mathrm{P}<0.05)$ or topical route (MD, $-93.52 ; 95 \% \mathrm{CI},-157.44$ to $-29.59 ; \mathrm{P}<0.05$ ), combined group showed significantly difference in total blood loss (Figure 4A).

\section{Postoperative HB level}

Nine studies reported postoperative $\mathrm{HB}$ level were included in this analysis. Five studies involving 585 patients compared combined TXA route with intravenous TXA and four studies involving 674 patients compared combined TXA route with topical TXA. The results showed that the combined route significantly increased postoperative $\mathrm{HB}$ level (MD, 0.54; 95\% CI, 0.45 to $0.64 ; \mathrm{P}<0.001 ; \mathrm{I}^{2}=71 \%$ ) compared with the single regimen. Either compared with the intravenous (MD, 0.74; 95\% CI, 0.61 to $0.87 ; \mathrm{P}<0.05$ ) or topical route (MD, $0.31 ; 95 \% \mathrm{CI}, 0.16$ to $0.45 ; \mathrm{P}<0.05$ ) showed significantly difference on postoperative HB level (Figure 4B).

\section{Transfusion rate}

Six studies involving 799 patients reported transfusion rate were included in this analysis. No significant difference was observed in the transfusion rate $(\mathrm{RR}, 0.62 ; 95 \% \mathrm{CI}$, 0.26 to $1.48 ; \mathrm{P}=0.28 ; \mathrm{I}^{2}=3 \%$ ) between combined TXA administration and single administration (Figure $4 C$ ).

\section{VTE rate}

Eight studies involving 1,128 patients reported on VTE rate were included in this analysis. No significant difference was observed in the VTE rate (RR, 0.81; 95\% CI, 0.57 to 1.15; $\left.\mathrm{P}=0.24 ; \mathrm{I}^{2}=0 \%\right)$ between combined TXA administration and single administration (Figure 4D).

\section{Sensitivity analysis and publication bias analysis}

Sensitivity analysis was also conducted to determine the impact on heterogeneity and evaluate the stability of the overall results by eliminating each study in turn. Our sensitivity analysis results show that our analysis was stable and reliable. We also conducted subgroup analysis and the results showed that surgery (bilateral TKA or unilateral TKA), region (Asia, Europe or North America), topical dose ( $\geq 3$ or $<3 \mathrm{~g}$ ), intravenous dose $(\geq 3$ or $<3 \mathrm{~g})$, tourniquet (use or not use) had no impact on the overall effect of the analysis. Funnel plot was performed to evaluate the publication bias of literature. The results suggested that there was no evidence of publication bias in the metaanalyses.

\section{Discussion}

TXA was widely used in primary TKA and the efficacy of TXA in reducing blood loss and transfusion rate has been reported in many studies, but the ideal route of administration has been controversial (36). At present, there is no unified standard for the administration of TXA, the most commonly method of TXA is intravenous injection and intra-articular topical injection, and some scholars think that the combination of the two can have a better effect $(11,35)$. Some scholars also think that oral administration of TXA can achieve the same effect and is more economical $(18,23)$. As there are many updated RCT studies comparing the administration of TXA, we carried out this metaanalysis to find the safest and effective method of using TXA in primary TKA.

The most important finding of this study was that the combined use of topical and intravenous administration of TXA is more beneficial than intravenous, topical or oral routes only. The results of this study suggested that the combined use of topical and intravenous administration of TXA reduced blood loss and preserved higher postoperative HB level than intravenous, topical or oral routes. In addition, there was no significant difference in the total 
A

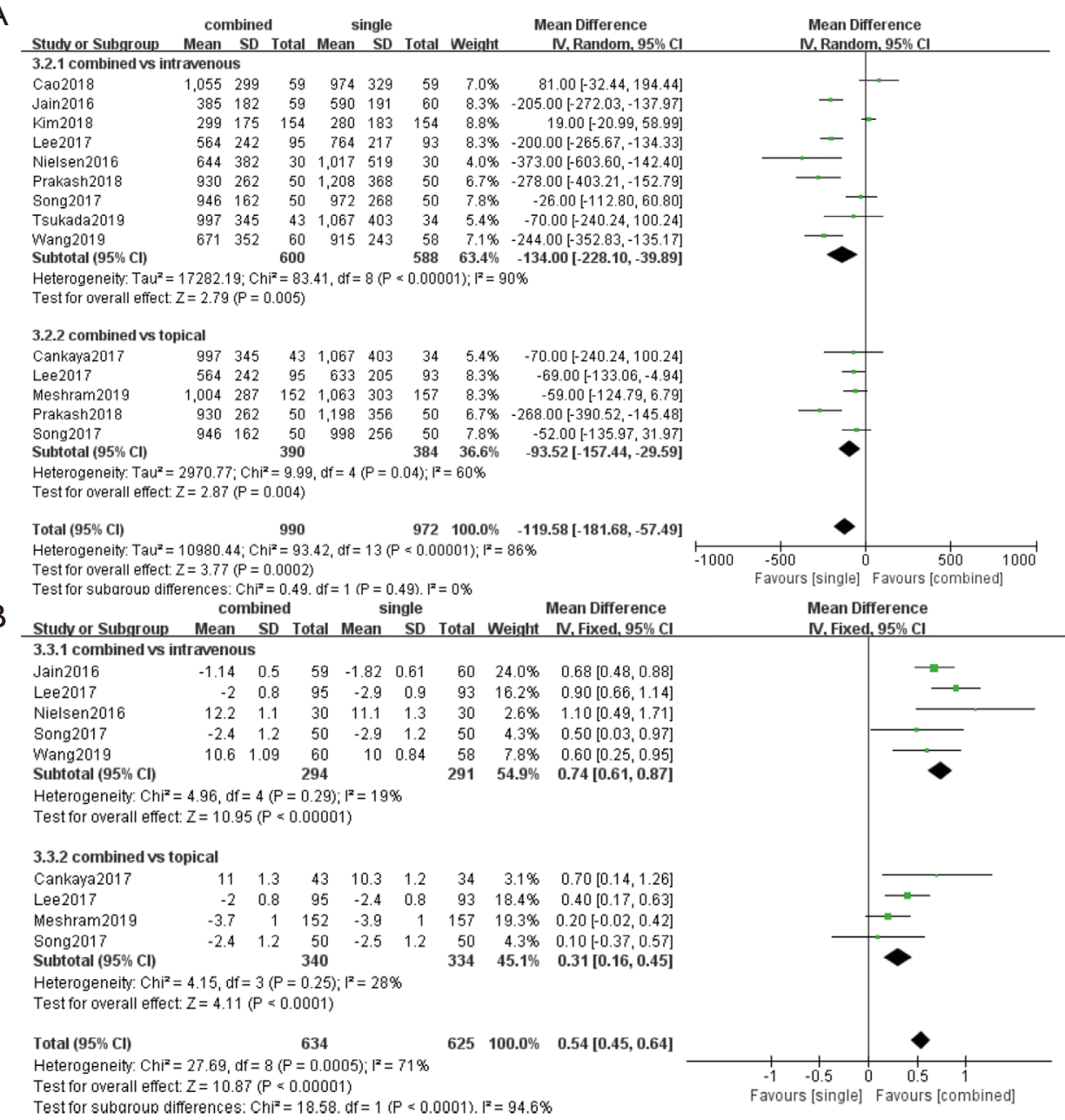

C

Test for subaroun differences: Chi $^{2}=18.58$. df $=1$ ( $\left.P<0.0001\right),\left.\right|^{2}=94.6 \%$

$$
\text { combined single Risk Ratio }
$$

Studv or Subgroup Events Total Events Total Weight $\mathrm{M}$-H, Fixed, 95\% Cl

$\begin{array}{lllllll}\text { Jain2016 } & 1 & 59 & 4 & 60 & 30.6 \% & 0.25[0.03,2.21]\end{array}$

$\begin{array}{lllllll}\text { King2019 } & 1 & 28 & 0 & 25 & 4.1 \% & 2.69[0.11,63.18\end{array}$

$\left.\begin{array}{llllllll}\text { Meshram2019 } & 2 & 152 & 0 & 157 & 3.8 \% & 5.16[0.25 & 106.68\end{array}\right]$

$\begin{array}{lrrrrrr}\text { Prakash2018 } & 0 & 50 & 4 & 50 & 34.7 \% & 0.11[0.01,2.01]\end{array}$

$\begin{array}{lllllll}\text { Song } 2017 & 0 & 50 & 1 & 50 & 11.6 \% & 0.33[0.01,7.99]\end{array}$

Wang 2019

258

Total $(95 \% \mathrm{Cl})$

Total events

397

Test for overall effect: $Z=1.08(P=0.28)$

D

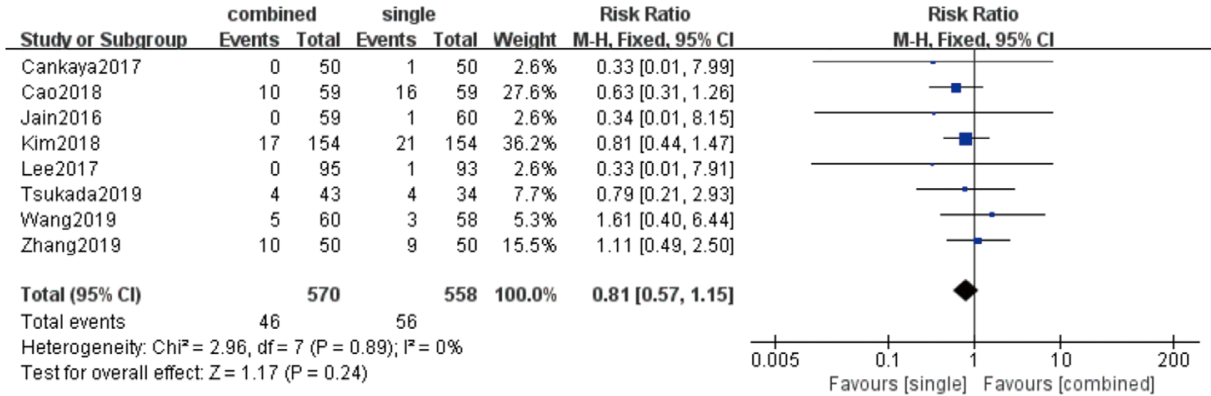

Figure 4 Forest plot between combined administration and single administration of tranexamic acid (A) blood loss. (B) Hemoglobin level. (C) Venous thrombotic events rate. (D) Transfusion rate. 
blood loss, blood transfusion rate and VTE rate after single administration of TXA. The only difference is that the postoperative HB level of topical TXA administration was significantly increased compared with the intravenous TXA administration. Although many studies have shown that intravenous or topical TXA administrations have the same effect $(24,33,34)$, our findings suggest that topical injection of TXA can be seen as a more effective route of single administration of TXA. There was no significant difference in blood loss and postoperative HB level between oral TXA and intravenous TXA or local TXA, which means that oral TXA can also be used as a method of clinical choice, and has more economic and convenient advantages. However, one meta-analyses have shown that topical and intravenous administration are equally effective in reducing blood loss and blood transfusion rate during TKA (6). Considering topical administration was a simple, surgeon-directed method, we believe topical administration of TXA could be an alternative of combined administration.

The use of topical or intravenous TXA in the setting of primary total joint arthroplasty has become routine practice because it has been shown to provide a clinical benefit and cost savings (40). However, there are still concerns about the safety of intravenous and oral TXA and the risk of thromboembolism in high-risk groups with a history of thromboembolism, acute myocardial infarction or ischemic cerebrovascular accident. Considering these safety issues, topical TXA can be a safe route of administration to reduce postoperative bleeding without increasing VTE associated with knee surgery (30). Our study confirmed that different administration did not significantly affect the incidence of postoperative VTE rate. It can be considered that the combination administration of TXA can bring the greatest benefits to patients without increasing the VTE rate.

The heterogeneity of this study was small, but we still do subgroup analysis. In our meta-analysis, we found that subgroups had no significant effect on the overall effect of the analysis. We believed that TXA had a good effect on reducing blood loss in both bilateral TKA and unilateral TKA and among different races, TXA can also play a good effect. There are still many disputes about the best amount of TXA, but this meta-analysis did not compare the amount of TXA in different groups. Subgroup analysis showed that there was no significant difference between the highdose group and the low-dose group, indicating that the use of low-dose TXA was equivalent to the use of high-dose TXA in reducing blood loss, but the optimal dose of TXA still needs further study. Some studies have shown that
TXA can play a good role in hemostasis in TKA without tourniquet $(10,14,15)$, so as to reduce the influence of tourniquet on postoperative rehabilitation. The subgroup of use tourniquet or not showed no statistically significant difference between the two groups.

There have been some meta-analyses on the efficacy and safety of TXA $(6,7,9)$. These studies have shown that intravenous, topical and oral TXA were effective and safe routes, among which intravenous TXA is the most common. Compared to these meta-analysis, our study has some unique advantages. First, all included studies were RCTs. In our meta-analysis, the latest research has been included, and a large amount of researches have been included, which enhances the persuasiveness of the research. Second, a number of subgroups including surgery, region, TXA dose and tourniquet were analyzed to find out the relevant factors. The final results showed that subgroups had no significant effect on the overall efficacy of the analysis. Admittedly, there were a few limitations in the current study that should not be ignored. First, although the administrations of using TXA were compared, the optimal dosage of TXA was not considered in this study. Second, because of the low incidence of blood transfusion and VTE, more samples are needed to improve the statistical ability. Thirdly, the calculation method of total blood loss was not uniform, the calculation formula of different authors was not consistent, and the factors of postoperative drainage tube were not considered.

\section{Conclusions}

This meta-analysis indicates that combined administration of TXA in primary TKA can significantly decrease total blood loss, postoperative HB drop compared with intravenous, topical or oral TXA alone. Oral administration of TXA is similar to intravenous or topical TXA use alone. No matter which administration, there is no significant difference between the postoperative transfusion rate and VTE rate.

\section{Acknowledgments}

Funding: This study was funded by National Natural Science Foundation of China (grant numbers 81972130, $81703896,81972107,82072494$ and 81902203), the National Key Research and Development Program of China (grant number 2017YFC0108102), and the Capital Health Research and Development of Special (grant 
number 2020-2-4067).

\section{Footnote}

Reporting Checklist: The authors have completed the PRISMA reporting checklist. Available at http://dx.doi. org/10.21037/apm-20-1857

Conflicts of Interest: All authors have completed the ICMJE uniform disclosure form (available at http://dx.doi. org/10.21037/apm-20-1857). The authors have no conflicts of interest to declare.

Ethical Statement: The authors are accountable for all aspects of the work in ensuring that questions related to the accuracy or integrity of any part of the work are appropriately investigated and resolved. The study was conducted in accordance with the Declaration of Helsinki (as revised in 2013). This meta-analysis does not require the approval of the ethics committee.

Open Access Statement: This is an Open Access article distributed in accordance with the Creative Commons Attribution-NonCommercial-NoDerivs 4.0 International License (CC BY-NC-ND 4.0), which permits the noncommercial replication and distribution of the article with the strict proviso that no changes or edits are made and the original work is properly cited (including links to both the formal publication through the relevant DOI and the license). See: https://creativecommons.org/licenses/by-nc-nd/4.0/.

\section{References}

1. Lee SH, Cho KY, Khurana S, et al. Less blood loss under concomitant administration of tranexamic acid and indirect factor Xa inhibitor following total knee arthroplasty: a prospective randomized controlled trial. Knee Surg Sports Traumatol Arthrosc 2013;21:2611-7.

2. Sculco TP, Baldini A, Keating EM. Blood management in total joint arthroplasty. Instr Course Lect 2005;54:51-66.

3. Chambers S, Tidwell L, Kerkhof A, et al. Topical Tranexamic Acid Is Effective in Cementless Total Knee Arthroplasty. Orthop Clin North Am 2020;51:7-11.

4. Porter SB, White LJ, Osagiede O, et al. Tranexamic Acid Administration Is Not Associated With an Increase in Complications in High-Risk Patients Undergoing Primary Total Knee or Total Hip Arthroplasty: A Retrospective Case-Control Study of 38,220 Patients. J Arthroplasty 2020;35:45-51.e3.

5. Jules-Elysee KM, Tseng A, Sculco TP, et al. Comparison of Topical and Intravenous Tranexamic Acid for Total Knee Replacement: A Randomized Double-Blinded Controlled Study of Effects on Tranexamic Acid Levels and Thrombogenic and Inflammatory Marker Levels. J Bone Joint Surg Am 2019;101:2120-8.

6. Sun Q, Li J, Chen J, et al. Comparison of intravenous, topical or combined routes of tranexamic acid administration in patients undergoing total knee and hip arthroplasty: a meta-analysis of randomised controlled trials. BMJ Open 2019;9:e024350.

7. Xiong $\mathrm{H}$, Liu $\mathrm{Y}$, Zeng $\mathrm{Y}$, et al. The efficacy and safety of combined administration of intravenous and topical tranexamic acid in primary total knee arthroplasty: a meta-analysis of randomized controlled trials. BMC Musculoskelet Disord 2018;19:321.

8. Chen X, Zheng F, Zheng Z, et al. Oral vs intravenous tranexamic acid in total-knee arthroplasty and total hip arthroplasty: A systematic review and meta-analysis. Medicine (Baltimore) 2019;98:e15248.

9. Han X, Gong G, Han N, et al. Efficacy and safety of oral compared with intravenous tranexamic acid in reducing blood loss after primary total knee and hip arthroplasty: a meta-analysis. BMC Musculoskelet Disord 2018;19:430.

10. Tsukada S, Kurosaka K, Nishino M, et al. Intra-articular tranexamic acid as an adjunct to intravenous tranexamic acid for simultaneous bilateral total knee arthroplasty: a randomized double-blind, placebo-controlled trial. BMC Musculoskelet Disord 2019;20:464.

11. Prakash J, Seon JK, Song EK, et al. Is Combined Administration of Tranexamic Acid Better than Both Intravenous and Topical Regimes for Total Loss, Hidden Loss and Post-operative Swelling? A Randomized Control Trial. Indian J Orthop 2018;52:117-23.

12. Moher D, Liberati A, Tetzlaff J, et al. Preferred reporting items for systematic reviews and meta-analyses: the PRISMA statement. BMJ 2009;339:b2535.

13. Higgins JP, Thompson SG. Quantifying heterogeneity in a meta-analysis. Stat Med 2002;21:1539-58.

14. King L, Randle R, Dare W, et al. Comparison of oral vs. combined topical/intravenous/oral tranexamic acid in the prevention of blood loss in total knee arthroplasty: A randomised clinical trial. Orthop Traumatol Surg Res 2019;105:1073-7.

15. Wang HY, Wang L, Luo ZY, et al. Intravenous and subsequent long-term oral tranexamic acid in enhancedrecovery primary total knee arthroplasty without the 
application of a tourniquet: a randomized placebocontrolled trial. BMC Musculoskelet Disord 2019;20:478.

16. Zhang YM, Yang B, Sun XD, et al. Combined intravenous and intra-articular tranexamic acid administration in total knee arthroplasty for preventing blood loss and hyperfibrinolysis: A randomized controlled trial. Medicine (Baltimore) 2019;98:e14458.

17. Meshram P, Palanisamy JV, Seo JY, et al. Combined Intravenous and Intraarticular Tranexamic Acid Does Not Offer Additional Benefit Compared with Intraarticular Use Alone in Bilateral TKA: A Randomized Controlled Trial. Clin Orthop Relat Res 2020;478:45-54.

18. Wang D, Wang HY, Cao C, et al. Tranexamic acid in primary total knee arthroplasty without tourniquet: a randomized, controlled trial of oral versus intravenous versus topical administration. Sci Rep 2018;8:13579.

19. Cao G, Xie J, Huang Z, et al. Efficacy and safety of multiple boluses of oral versus intravenous tranexamic acid at reducing blood loss after primary total knee arthroplasty without a tourniquet: A prospective randomized clinical trial. Thromb Res 2018;171:68-73.

20. Abdel MP, Chalmers BP, Taunton MJ, et al. Intravenous Versus Topical Tranexamic Acid in Total Knee Arthroplasty: Both Effective in a Randomized Clinical Trial of 640 Patients. J Bone Joint Surg Am 2018;100:1023-9.

21. Kim YH, Pandey K, Park JW, et al. Comparative Efficacy of Intravenous With Intra-articular Versus Intravenous Only Administration of Tranexamic Acid to Reduce Blood Loss in Knee Arthroplasty. Orthopedics 2018;41:e827-30.

22. Wei W, Dang S, Duan D, et al. Comparison of intravenous and topical tranexamic acid in total knee arthroplasty. BMC Musculoskelet Disord 2018;19:191.

23. Wang D, Zhu H, Meng WK, et al. Comparison of oral versus intra-articular tranexamic acid in enhancedrecovery primary total knee arthroplasty without tourniquet application: a randomized controlled trial. BMC Musculoskelet Disord 2018;19:85.

24. Subramanyam KN, Khanchandani P, Tulajaprasad PV, et al. Efficacy and safety of intra-articular versus intravenous tranexamic acid in reducing perioperative blood loss in total knee arthroplasty: a prospective randomized doubleblind equivalence trial. Bone Joint J 2018;100-B:152-60.

25. Yen SH, Lin PC, Chen B, et al. Topical Tranexamic Acid Reduces Blood Loss in Minimally Invasive Total Knee Arthroplasty Receiving Rivaroxaban. Biomed Res Int 2017;2017:9105645.

26. George J, Eachempati KK, Subramanyam KN, et al. The comparative efficacy and safety of topical and intravenous tranexamic acid for reducing perioperative blood loss in Total knee arthroplasty- A randomized controlled noninferiority trial. Knee 2018;25:185-91.

27. Lacko M, Cellar R, Schreierova D, et al. Comparison of intravenous and intra-articular tranexamic acid in reducing blood loss in primary total knee replacement. Eklem Hastalik Cerrahisi 2017;28:64-71.

28. Wang J, Wang Q, Zhang X, et al. Intra-articular Application is More Effective Than Intravenous Application of Tranexamic Acid in Total Knee Arthroplasty: A Prospective Randomized Controlled Trial. J Arthroplasty 2017;32:3385-9.

29. Stowers MDJ, Aoina J, Vane A, et al. Tranexamic Acid in Knee Surgery Study-A Multicentered, Randomized, Controlled Trial. J Arthroplasty 2017;32:3379-84.

30. Lee SY, Chong S, Balasubramanian D, et al. What is the Ideal Route of Administration of Tranexamic Acid in TKA? A Randomized Controlled Trial. Clin Orthop Relat Res 2017;475:1987-96.

31. Cankaya D, Dasar U, Satilmis AB, et al. The combined use of oral and topical tranexamic acid is a safe, efficient and low-cost method in reducing blood loss and transfusion rates in total knee arthroplasty. J Orthop Surg (Hong Kong) 2017;25:2309499016684725.

32. Tzatzairis TK, Drosos GI, Kotsios SE, et al. Intravenous vs Topical Tranexamic Acid in Total Knee Arthroplasty Without Tourniquet Application: A Randomized Controlled Study. J Arthroplasty 2016;31:2465-70.

33. May JH, Rieser GR, Williams CG, et al. The Assessment of Blood Loss During Total Knee Arthroplasty When Comparing Intravenous vs Intracapsular Administration of Tranexamic Acid. J Arthroplasty 2016;31:2452-7.

34. Song EK, Seon JK, Prakash J, et al. Combined Administration of IV and Topical Tranexamic Acid is Not Superior to Either Individually in Primary Navigated TKA. J Arthroplasty 2017;32:37-42.

35. Nielsen CS, Jans Ø, Ørsnes T, et al. Combined IntraArticular and Intravenous Tranexamic Acid Reduces Blood Loss in Total Knee Arthroplasty: A Randomized, DoubleBlind, Placebo-Controlled Trial. J Bone Joint Surg Am 2016;98:835-41.

36. Fillingham YA, Kayupov E, Plummer DR, et al. Rand Young Investigator's Award: A Randomized Controlled Trial of Oral and Intravenous Tranexamic Acid in Total Knee Arthroplasty: The Same Efficacy at Lower Cost? J Arthroplasty 2016;31:26-30.

37. Aggarwal AK, Singh N, Sudesh P. Topical vs Intravenous Tranexamic Acid in Reducing Blood Loss After Bilateral 
Total Knee Arthroplasty: A Prospective Study. J Arthroplasty 2016;31:1442-8.

38. Jain NP, Nisthane PP, Shah NA. Combined Administration of Systemic and Topical Tranexamic Acid for Total Knee Arthroplasty: Can It Be a Better Regimen and Yet Safe? A Randomized Controlled Trial. J Arthroplasty 2016;31:542-7. 39. Chen JY, Chin PL, Moo IH, et al. Intravenous versus

Cite this article as: Lu F, Sun X, Wang W, Zhang Q, Guo W. What is the ideal route of administration of tranexamic acid in total knee arthroplasty? A meta-analysis based on randomized controlled trials. Ann Palliat Med 2021;10(2):1880-1894. doi: 10.21037/apm-20-1857 intra-articular tranexamic acid in total knee arthroplasty: A double-blinded randomised controlled noninferiority trial. Knee 2016;23:152-6.

40. Charoencholvanich K, Siriwattanasakul P. Tranexamic acid reduces blood loss and blood transfusion after TKA: a prospective randomized controlled trial. Clin Orthop Relat Res 2011;469:2874-80. 